Teaching Neuro/mage

\title{
Thromboembolic stroke in ICA stenosis
}

\author{
Stefan Isenmann, MD; Martin Skalej, MD; and Johannes Dichgans, MD
}

A 74-year-old man with right-sided amaurosis fugax had an ultrasound examination revealing right internal carotid artery (ICA) stenosis (figure 1, A and B). Angiography (figure 2A) showed a proximal ICA stenosis of approximately 90\% according to NASCET criteria ${ }^{1}$ and a distal thrombus. The patient was anticoagulated with heparin. Invasive treatment options were discussed, but 16 hours later the patient had a stroke (figure 2B), with left sided hemiplegia and hemineglect. The insult was caused by arterio-arterial thromboembolism rather than ICA occlusion, because follow-up ultrasound showed the right ICA still with the same high degree of stenosis (figure 1, C and D). In ICA stenosis, embolic cerebral infarction is usually ascribed to plaque rupture, and imaging often shows multiple emboli., ${ }^{2,3}$ In contrast, here the heterozygous factor V Leiden mutation (R506Q) may have contributed to thrombus formation in the post-stenotic artery.,5

\section{References}

1. North American Symptomatic Carotid Endarterectomy Trial Collaborators. Beneficial effect of carotid endarterectomy in symptomatic patients with high-grade carotid stenosis. $\mathrm{N}$ Engl J Med 1991;325:445-453.

2. Spagnoli LG, Mauriello A, Sangiorgi G, et al. Extracranial thrombotically active carotid plaque as a risk factor for ischemic stroke. JAMA 2004;292:1845-1852.

3. Kastrup A, Schulz JB, Mader I, et al. Diffusion-weighted MRI in patients with symptomatic internal carotid artery disease. J Neurol 2002;249:1168-1174.

4. Casas JP, Hingorani AD, Bautista LE, Sharma P. Meta-analysis of genetic studies in ischemic stroke: thirty-two genes involving approximately 18,000 cases and 58,000 controls. Arch Neurol 2004;61:1652-1661.

5. Kim RJ, Becker RC. Association between factor V Leiden, prothrombin G20210A, and methylenetetrahydrofolate reductase C677T mutations and events of the arterial circulatory system: a meta-analysis of published studies. Am Heart J 2003;146:948-957.
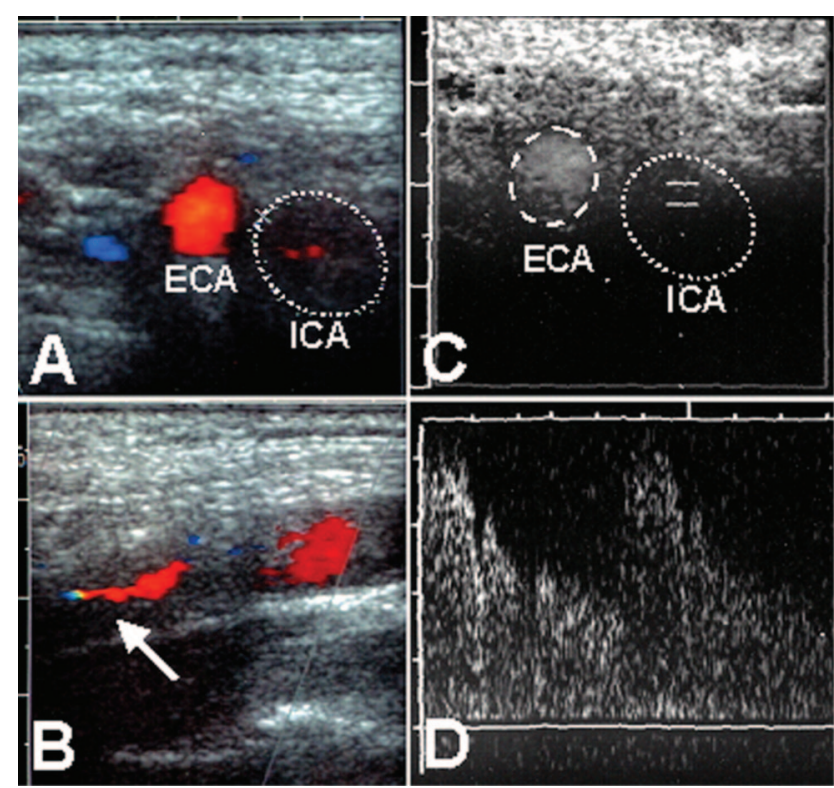

Figure 1. Ultrasound examinations. A, B, prestroke: cross (A) and longitudinal (B) sections showing only minute residual flow signal (red; arrow in B) in the right internal carotid artery (ICA) $(10 \mathrm{kHz}$, maximal systolic velocity: $>300$ $\mathrm{cm} / \mathrm{second})$. $C, D$, poststroke: cross section $(C)$ with flow measurement $(D,>13$ $\mathrm{kHz}$, maximal systolic velocity: $>200 \mathrm{~cm} /$ second, consistent with a $90 \%$ stenosis). The original ICA lumen is outlined with a dotted line in A, C.
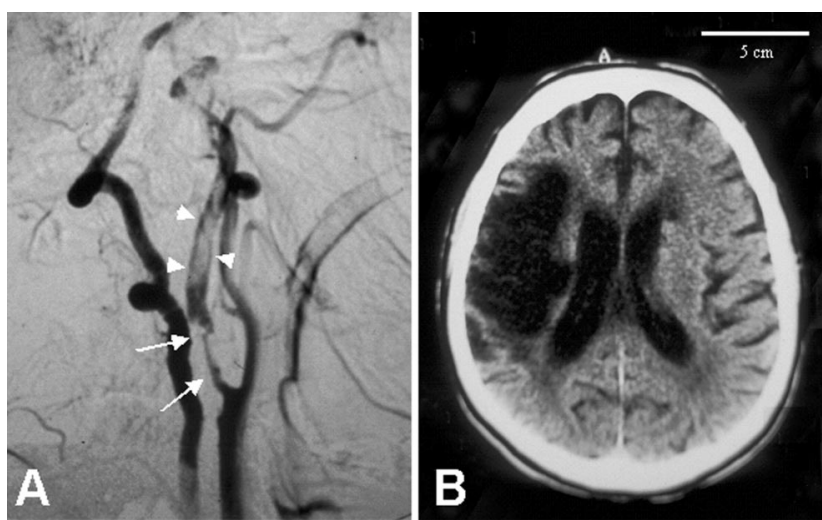

Figure 2. DSA (A) showing a 90\% stenosis of the proximal right internal carotid artery (ICA) (arrows), and a thrombus located distal to the stenosis (arrowheads), occupying most of the ICA diameter. Cranial CT scan (B) 3 months later showing a large demarcated infarction of the right $M C A$ territory (scale bar, $5 \mathrm{~cm}$ ).

From the Departments of Neurology (Drs. Isenmann and Dichgans) and Neuroradiology (Dr. Skalej), University of Tübingen Medical School, Germany. Dr. Skalej is currently with the University of Magdeburg, Department of Neuroradiology, Magdeburg, Germany. Dr. Isenmann is currently with the University of Jena, Department of Neurology, Jena, Germany.

Disclosure: The authors report no conflicts of interest.

Address correspondence and reprint requests to Dr. Stefan Isenmann, University of Jena Medical School, Department of Neurology, Erlanger Allee 101, D-07747 Jena, Germany; e-mail: stefan.isenmann@med.uni-jena.de 


\section{Neurology}

\section{Teaching NeuroImage: Thromboembolic stroke in ICA stenosis \\ Stefan Isenmann, Martin Skalej and Johannes Dichgans \\ Neurology 2005;65;E16 \\ DOI 10.1212/01.wnl.0000178887.74545.0d}

This information is current as of October 10, 2005

\author{
Updated Information \& \\ Services \\ Supplementary Material \\ References \\ Permissions \& Licensing \\ Reprints
}

including high resolution figures, can be found at: http://n.neurology.org/content/65/7/E16.full

Supplementary material can be found at: http://n.neurology.org/content/suppl/2007/04/02/65.7.E16.DC1

This article cites 5 articles, 0 of which you can access for free at: http://n.neurology.org/content/65/7/E16.full\#ref-list-1

Information about reproducing this article in parts (figures,tables) or in its entirety can be found online at:

http://www.neurology.org/about/about_the_journal\#permissions

Information about ordering reprints can be found online:

http://n.neurology.org/subscribers/advertise

Neurology ${ }^{\circledR}$ is the official journal of the American Academy of Neurology. Published continuously since 1951, it is now a weekly with 48 issues per year. Copyright . All rights reserved. Print ISSN: 0028-3878. Online ISSN: 1526-632X.

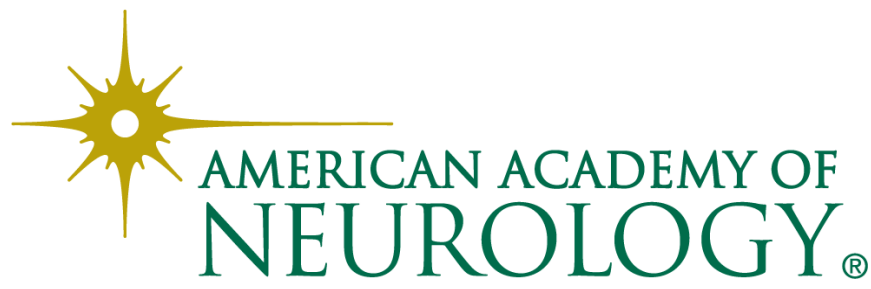

